\title{
Agentes Locales Ambientales (ALAs): Hacia la ciudad sostenible
}

\author{
Local Environmental Agents (ALAs): \\ Towards the sustainable city
}

\author{
$\underline{\text { S. Marín-Herbert }}^{(*)}$
}

\section{RESUMEN}

Partiendo de un marco de referencia, como la Agenda Local 21 (1) o la Carta de Leipzig (2), cualquier acción encaminada a una mejora en la calidad de vida de una ciudad a través de modelos urbanos más sostenibles, requiere una modificación en las conductas de sus habitantes. El proyecto ALAs, motiva este cambio a través del paso directo a la acción liderada por los más jóvenes a través del Sistema Educativo quien mediante un efecto multiplicador (compañeros, familiares, vecinos) y a través de la acción directa en sus barrios, consigue fomentar la participación autónoma de la población en la mejora de la sostenibilidad (3)y la calidad de vida de su ciudad. A la secuencia "concienciación - acción - medición - motivación se han incorporado herramientas como el GIS que apoyan la estrategia de acción en los barrios controlando su eficacia y eficiencia en la consecución de los objetivos.

113-129

Palabras clave: Sostenibilidad urbana; barrios; participación; acción directa.

\section{SUMMARY}

Any action aimed at improving the quality of life in a city through more sustainable urban models, based on a reference framework such as the Local Agenda 21 or the, calls for changes to its inhabitants' behaviour. The ALAs project drives this change by making the city's youngest inhabitants Leaders of Change. They involve others (school friends, family members, neighbours) in direct action in their neighbourhood, making the community participate independently in improving the city's sustainability and quality of life. To the sequence "awareness-raising - action - monitoring - motivation tools such as our Geographical Information System have been added to support the neighbourhood action strategy by monitoring its efficiency and its effectiveness at meeting targets.

Keywords: Urban sustainability; neighbourhoods; participation; direct action. 


\section{INTRODUCCIÓN}

\subsection{La estructura}

Parte del éxito del proyecto se basa en la estructura de actores clave que lo promueve. El Ayuntamiento de Málaga, cuenta con una extensa experiencia en la coordinación de proyectos y redes con una influencia directa en políticas públicas ligadas al medio ambiente urbano. El promotor del proyecto, el Observatorio de Medio Ambiente Urbano (OMAU), www.omau-malaga.com El OMAU, cuya labor ha sido reconocida internacionalmente por organismos como el Comité Habitat de Naciones Unidas o la Unión Europea, está directamente vinculado a las principales actuaciones ligadas al Medio Ambiente Urbano (4) en la ciudad. Responsable de la Agenda Local 21, percibe y promueve el medio ambiente urbano como la integración de cuatro grandes grupos de trabajo: el territorio y la configuración de la ciudad; la gestión de los recursos naturales; la cohesión social y el desarrollo económico; el Gobierno de la ciudad y la participación ciudadana.

La articulación de esos ámbitos de trabajo de desarrolla a través de un sistema integrado de indicadores urbanos desarrollado en base a un Sistema de Información Geográfica en software libre de acuerdo a la directiva Europea "Inspire", clave en la Agenda Local 21 de la ciudad y principal herramienta estratégica de apoyo a las acciones en los barrios de los ALAs.

Esta organización de base otorga al OMAU la oportunidad de vertebrar desde el ámbito técnico, y con el respaldo político al marco teórico de referencia, a los organismos claves de la ciudad. Además de la dirección de proyecto desde el OMAU y la ejecución a través del Aula de la Naturaleza las Contadoras de Málaga, participan en el proyecto otros organismos e instituciones como la Agencia Municipal de la Energía, la Empresa Malagueña de Transportes, el Área de Tráfico a través del Plan Municipal de Movilidad Sostenible, así como asociaciones como Madre Coraje o Ruedas Redondas o empresas privadas como IKEA Málaga. Sin embargo sin la participación ciudadana, principal actor de esta estructura, no es posible un cambio de actitud capaz de producir resultados de impacto en la ciudad. Esta participación, se motiva desde la acción de los auténticos líderes, los niños, convertidos a través del proyecto en Agentes Locales Ambientales.

\subsection{Objetivos}

A la consecución de los objetivos establecidos en la Agenda Local 21 de Málaga como objetivo principal, se suman:

\section{INTRODUCTION}

\subsection{The structure}

Part of the project's success is based on the key actors' structure behind The Málaga City Council is a public administration with a wealth of experience in coordinating projects and networks that have a direct influence on public policies specifically related to the Urban Environment. The promoter of the project, the Urban Environment Observatory (OMAU) www.omau-malaga.com, whose work has been internationally recognised by organisations such as the UNHabitat Committee or the European Union, is directly linked to the main initiatives developed in Urban Environment. As the body responsible for Local Agenda 21, it recognises and promotes the urban environment as the integration of four principal areas of work: territory and city configuration, the management of natural resources, social cohesion and economic development \& governance and citizen participation.

The articulation of these 4 working areas is made via an integrated system of urban indicators developed on a Geographical Information System (GIS) platform (based on a open source software under the European Directive "ISNPIRE") and plays a key role in the Malaga Local Agenda 21 \& is the main tool for providing strategic support to the activities carried out by the Local Environmental Agents.

This background gives the OMAU the opportunity to involve, from a technical viewpoint and with the political support to its strategic framework, the key institutions of the City. In addition to the management of the Project by the OMAU and it's execution by the Aula de la Naturaleza Las Contadoras de Málaga, other groups and institutions participate in the project such as the $\mathrm{Mu}$ nicipal Energy Agency, the Málaga Transport Company (EMT), the Municipal Traffic and Transport Area (through its Sustainable Mobility Plan), associations such as Madre Coraje or Ruedas Redondas and private companies such as IKEA Málaga. However, a change of attitude, capable of producing significant results in the city is not possible without the citizen's participation, main actor of these structure. This involvement is encouraged by the action of the real leaders, the children, recruited by the project as Local Environment Agents.

\subsection{Objectives}

In addition to those established as part of Málaga's local Agenda 21, the following objectives should be included: 
- Promover un modelo urbano más sostenible caracterizado por su compacidad y complejidad desde la participación activa de la ciudadanía liderada por los más jóvenes.

- Promover la auto-organización ambiental progresiva del Sistema Educativo de Málaga y su apertura y participación en la vida de los barrios.

- Poner en práctica algunos de los Principios Rectores de la Actuación Ambiental Urbana de la Carta Verde de Málaga (5) (Principio de información / Principio de vecindad / Principio de responsabilidades compartidas)

- Fomentar la autonomía y la participación de profesores, escolares, familias y barrios a través de la generación de ideas y propuestas de actuación y participación ciudadanas que complementen las actuaciones ambientales del Ayuntamiento de Málaga colaborando en la mejora de determinados Indicadores de la Agenda Local 21. (6)

- Ampliar el ámbito de actuación y repercusión geográfica del proyecto mediante su internacionalización y trabajo en red, actualmente desarrollada con las ciudades del norte de Marruecos: Tánger, Tetuán, Alhucemas y Nador.

\section{TARGET}

Los destinatarios más directos del proyecto son alumnos y profesores de Centros Educativos de Primaria, Secundaria y Bachillerato que pertenezcan a la jurisdicción de la ciudad de Málaga o su área metropolitana. Los alumnos se convierten en diseñadores y ejecutores de las actividades, promotores del cambio a través de un efecto que empieza con sus compañeros de colegio y continúa a través de las acciones de barrio con vecinos, amigos, familiares, comerciantes, asociaciones, etc. El efecto multiplicador que puede apreciarse en la Figura 1 , se establece en función a 3 ejes clave, colegio-vecinos-hogares.
- Promote a more sustainable urban model compact and complex, from the active participation of their citizens, lead by the youngest population.

- Promote the progressive concern of the local education system in Málaga regarding environmental issues and encourage their active participation in local areas and neighbourhoods.

- Put into practice some of the main standards stated in the original Local Agenda 21 for Malaga (Standard principles of information, neighbourhood \& shared responsibilities).

- Encourage the autonomy and participation of teachers, students, families and neighbourhoods through the generation of ideas, proposals for action and citizen participation which will complement the environmental actions of the Malaga City Council, helping to improve specific Local Agenda 21 indicators.

- Extend the project to other geographical areas, something that cab be seen currently with the established network with cities in North Morocco: Tangiers, Tetuan, Alhucemas and Nadir.

\section{TARGET}

The target audience of the project are pupils and teachers of Primary, Secondary and 6th Form Centres of Education which fall under the jurisdiction of the City of Malaga and it's Metropolitan area. The pupils will be in charge of designing and executing the activities, promoting change, starting with their class mates and expanding this effect by carrying out a series of actions with neighbours, relatives, shopkeepers and associations in the local area. The multiplying effect shown in Figure 1 is based on 3 key axis, schoolsneighbours - homes.
1. Efecto Multiplicador / Multiplying effect.

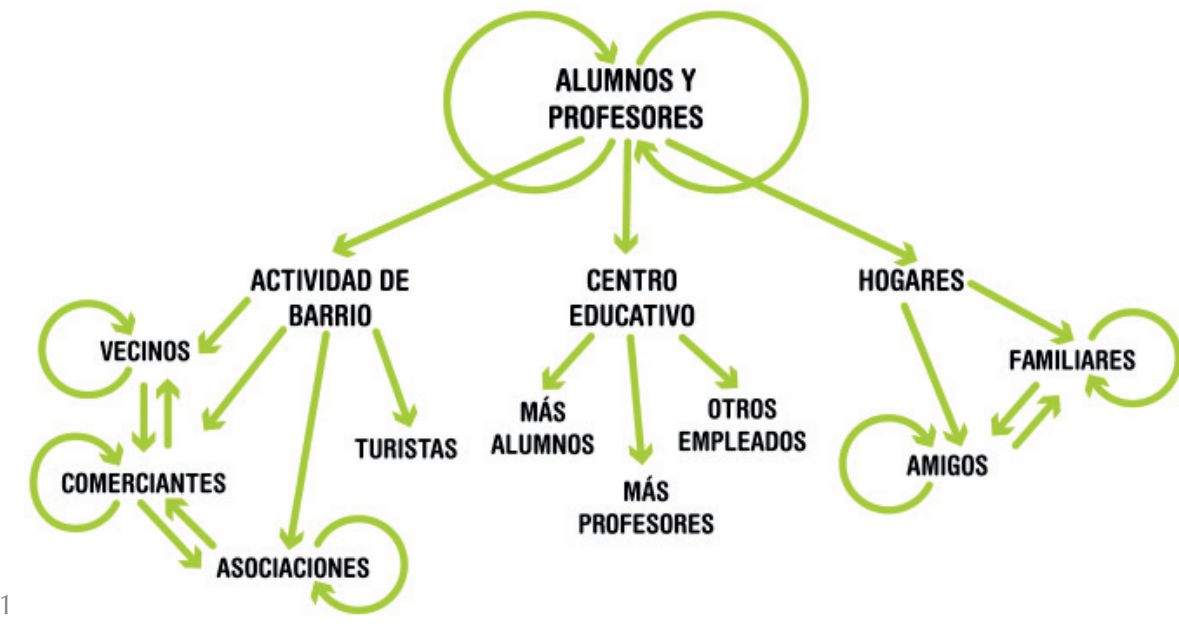


El impacto del proyecto alcanza de manera directa al entorno más inmediato de los ALAs, es decir, su comunidad educativa mediante compañeros de clase; familiares y vecinos así como comercios y habitantes de su barrio. Las actividades de barrio comienzan con un estudio de las zonas que se van a visitar a través de un Sistema de Información Geográfico. Este innovador instrumento permite conocer de antemano la situación de las zonas con más número de comercios, la densidad de población, accesos, zonas verdes, etc. De esta forma, se consigue la máxima eficiencia en las actividades de barrio. Se estima que el área de influencia de los ALAs en las actividades de barrio se extiende unos 300 metros alrededor de los comercios visitados con lo que podemos conocer la cantidad aproximada de ciudadanos que estarán bajo la influencia de las campañas de acción directa.

\section{METODOLOGÍA}

La metodología empleada (7) se basa en la formación de líderes naturales de concienciación como los jóvenes, para que mediante un efecto multiplicador de la acción directa en sus barrios, produzcan un cambio en la población que forma su entorno. La propia selección de colegios participantes, apoyada por el GIS, asegura una cobertura de toda la ciudad clasificada por las zonas naturales contempladas en el propio planeamiento.

Este sistema de trabajo cuenta con claras ventajas:

- Aumenta la eficiencia y eficacia de la intervención.

- La relación costes-resultados disminuye significativamente al aumentar el número de destinatarios indirectos de influencia.

- Aumenta la implicación de los destinatarios directos del proyecto siendo ellos mismos los actores del cambio de actitudes de la población.

- Fomenta la autonomía y la participación ciudadana a favor de la mejora de la calidad de vida de su propia ciudad colaborando a su Sostenibilidad a través de la acción.

\subsection{Bloques Temáticos}

La selección de las problemáticas medioambientales urbanas para cada curso escolar, aunque pueden sufrir adaptaciones en función de las estrategias de sostenibilidad de la ciudad, están habitualmente ligadas a los siguientes bloques temáticos (10):

- Ahorro y uso racional del agua: nuevos hábitos para la reducción del consumo
The project will have an impact in the immediate surrounding area of the Local Agents, such as their school environment, through class mates and their local village or town through family members, neighbors, shopkeepers and other people who live in the area. Before the activities are started in the neighborhood, a study of the local area is carried out using the GIS. This innovative tool provides us with prior knowledge of the layout of the local area, highlighting those areas with a high concentration of shops, population density, access to green zones, etc. This way, maximum efficiency is gained in the neighborhood actions. It is estimated that the impact of the activities carried out by the Local Agents extends to around $300 \mathrm{~m}$ from the places that they visit. This information allows us to ascertain the approximate number of citizens who will be influenced by these activities.

\section{METHODOLOGY}

The methodology employed is based on the training of natural awareness leaders, such as young people, so that through a multiplying effect of the direct action in their neighborhoods, they may provoke change in their surrounding area. The selection of participating schools, supported by the GIS, ensures a complete coverage of all areas included in the city planning.

This way of working has several advantages:

- It increases the efficiency and effectiveness of the intervention.

- The relationship between the costs and results is significantly reduced as the number of people indirectly influenced is increased.

- It increases the involvement of the target audience of the project, as they themselves are directly responsible for changing the attitudes of the population.

- It encourages the citizens' autonomy and participation in the project with the end result of improving the quality of life in their own city by acting to achieve sustainability.

\subsection{Thematic Iniciatives}

The problems of the urban environment which are to be tackled by the schools, despite being subject to the city's own sustainability strategies, usually fall into the following categories:

- The conservation and reasonable use of water: new habits for the reduction of its consumption.

- The conservation and efficient use of energy: new habits for the reduction of 
- Ahorro y uso eficiente de la energía: nuevos hábitos para la reducción del consumo y nuevas tecnologías para la eficiencia energética.

- Fomento del reciclaje: concienciación sobre ciclo de vida del producto, reciclaje y cooperación.

- Movilidad sostenible: fomento del uso del transporte público y medios de transporte más sostenible.

- Cohesión Social: mix de rentas, generacional y cultural en los barrios.

La integración de estos ámbitos sobre la base de un modelo urbano de ciudad compacta y compleja constituye la base teórica que marca la senda del proyecto. Cada colegio, en el momento de inscribirse en el proyecto, elige el/los bloques temáticos sobre los que quiere trabajar así como la posibilidad de que la familia (de manera individualizada) quiera participar en la línea de hogares verdes ALA.

\subsection{Fases}

El comienzo de campaña/ curso escolar arranca con una reunión con los grandes artífices del proyecto, los profesores, con los que se discuten las posibles mejoras convirtiendo el proyecto en un elemento vivo. La secuencia de actuación pasa por las siguientes fases:

\subsubsection{Captación}

Tras la invitación a participar a todos los colegios públicos y privados de primaria y secundaria, se realiza una selección con criterios como la validez geográfica de muestreo. Mediante la georeferenciación de los colegios (Figura 2), seleccionamos a centros de todas las áreas de la ciudad de forma que la muestra sea representativa y las actuaciones tengan un mayor impacto. consumption, and new technology to promote energy efficiency.

- Development of recycling: awareness of a product's life cycle, recycling and cooperation.

- Sustainable mobility: encouraging the use of public transport and more sustainable modes of transport.

- Social Cohesion: promote incomes generational and cultural mix in the neighbourhood.

The integration of these elements, based on the urban model of a compact and complex city, constitutes the theoretical frame which sets the project strategy. Each school, when signing up to the project, chooses the thematic initiatives in which they want to work on, as well as the possibility of families participating to the Green Homes ALA working line.

\subsection{Phases}

The initial phase of the campaign at the beginning of the school year will start with a meeting of the key players in the project, the teachers, and a discussion about possible improvements ensuring the project is always kept "alive". The following phases are involved:

\subsubsection{Recruitment}

After inviting all Primary and Secondary State and Private schools to participate, a selection process will take place with criteria such as the geographical distribution of the sample. Through a geographical reference of the schools (Figure 2), we will select schools throughout the city so that the sample will be representative, and that the activities will have maximum impact.

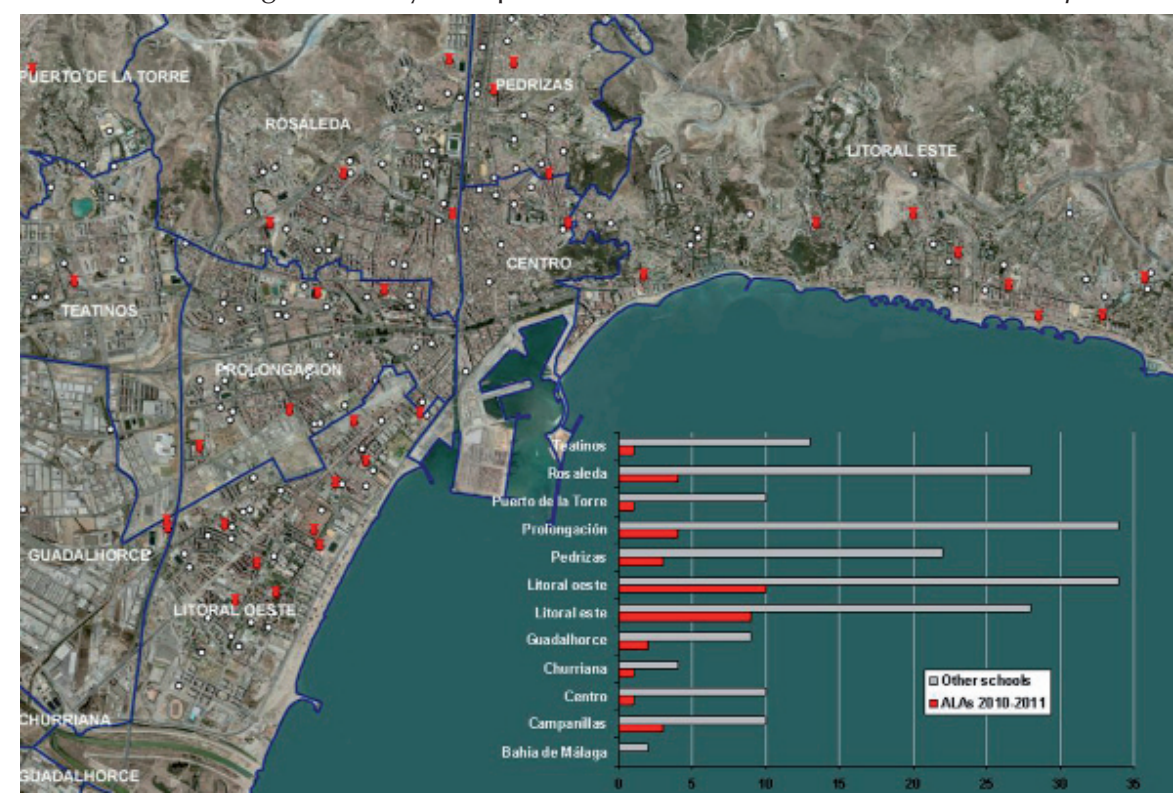


La participación de cada centro se concentra en un máximo de 2 clases (aproximadamente 60 alumnos) y sus profesores. Este "Equipo ALAs" será el que abanderará al Centro Educativo y se encargará de guiar, fomentar y ejecutar las actividades que se realicen tanto en su centro como en su barrio, convirtiéndose así en ejecutores de las acciones, en Agentes Ambientales de sus barrios.

En paralelo, se convoca a universitarios a través del centro del voluntariado de la Universidad de Málaga para participar en las acciones de barrio apoyando a los niños en las actuaciones.

Por otro lado se invita en esta fase de captación a los chicos a participar desde sus casas como "hogar verde ALA" (8), lo que implica un compromiso para la reducción de consumos de agua y energía durante el curso escolar, proporcionar información sobre la facturación de ambos servicios y el uso de un "kit básico para el hogar" que les ayudará a conseguir los objetivos de ahorro. Al mismo tiempo se integran en una red a nivel nacional de hogares modelo de sostenibilidad.

\subsubsection{Concienciación / formación}

Mediante charlas, videos, ejemplos prácticos y otros recursos didácticos, esta fase permite la toma de contacto y/o la ampliación de conocimientos de los ALAs con el bloque temático a tratar. De esta forma, se pasa a la toma de conciencia de la realidad del problema ambiental urbano que dará lugar a una estimulación para participar activamente en la búsqueda de soluciones. En el caso del bloque de movilidad, se realiza un taller práctico en los colegios participantes sobre el uso y mantenimiento de la bicicleta como medio principal de transporte en colaboración con asociaciones ligadas a la bicicleta y el Plan de Movilidad Sostenible del Ayuntamiento.

Esta fase se completa con la visita de los centros al Observatorio de Medio Ambiente Urbano de Málaga donde, tras mostrar su misión y las características de un edificio bioclimático, se les da una charla sobre el medio ambiente en general y su ámbito urbano para que entiendan como un modelo urbano sostenible debe integrar todas las temáticas que el proyecto trabaja y no considerarlas de manera aislada.

\subsubsection{Acción}

En esta fase se procede a la puesta en marcha de acciones tanto en los colegios como en los barrios donde están ubicados los centros
The involvement of each centre will be concentrated in a maximum of 2 classes (approximately 60 pupils) and their teachers. This 'Local Agent Team' will lead the way for the School and be responsible for guiding, encouraging and performing the activities to be carried out in the centre as well as the neighbourhood, becoming project's actions executers or Local Environmental Agents in their districts.

In parallel, students from the University of Malaga are invited to participate through their Volunteers Office, supporting the children in the neighbourhood actions.

Additionally at this phase, the agents will be encouraged to participate in their own homes, making them 'ALAs Green Homes' with the aim of reducing energy and water consumption during the school year. They will also provide information about the billing of both services and be given a 'basic home kit' that will help them to achieve these objectives. At the same time they will be involved in a national network of sustainable homes.

\subsubsection{Awareness / training}

Through talks, videos, practical examples and other educational resources, the Local Agents will be trained in the different areas of interest. By following this method, an awareness of the reality of the problem facing the urban environment will give way to an incentive to actively participate in the search for solutions. In the case of Mobility, a practical workshop will take place in the participating schools advising on the use and maintenance of bicycles as a main means of transport in collaboration with cycling associations and the Town Council's Plan for Sustainable Mobility.

This phase will conclude with a visit to Malaga's OMAU where, after explaining their mission and the characteristics of a bioclimatic building, they will hear a talk on the environment in general and a focus on urban areas. These pretends to help them understand that a sustainable urban model must integrate all thematic areas they are working with, not considering them isolated.

\subsubsection{Action}

This phase involves the implementation of actions in both schools and their surrounding neighbourhoods. The mission of the Environmental Local Agents in schools is to act as a spokesperson to raise the environmental conscience, implicit in the campaign, with the intention of making the school as 
educativos. El cometido de los Agentes Locales Ambientales en los centros escolares es actuar como propulsores de la concienciación ambiental en las campañas tratadas para conseguir que el entorno escolar sea más respetuoso con el medio ambiente. Esta importante tarea la desarrollan a través de campañas que ellos mismos diseñan y donde transmiten a los compañeros a través de pequeñas acciones lo tratado en las charlas.

La acción en los barrios es una de las iniciativas más novedosas de este proyecto ya que hace que los Agentes Locales Ambientales sean un punto clave en el avance de la ciudad de Málaga hacia los objetivos establecidos en su Agenda Local 21. Para la acción en los barrios, el proyecto cuenta a través del OMAU con un instrumento clave como el SIG que permite un análisis previo de la zona donde se va a realizar la actividad con el fin de conocer la distribución del barrio, definir el área de actuación y conocer datos sociodemográficos como densidad de población, tipo de comercios, situación de los contendores de reciclado, tipo de población, etc. Esta herramienta cuya información se traslada a fichas como la que se muestra en la Figura 3, nos permite optimizar la organización de la acción maximizando su impacto. a whole, more respectful towards the environment. This important task is developed through campaigns which the students design themselves and through which they aim to communicate to fellow class mates the content of the different talks which they have attended via different actions.

Action in the neighbourhoods is one of the most novel initiatives of this project since the Local Environmental Agents will be key factors in helping the city of Málaga accomplish the objectives established in the Local Agenda 21. With regards to the action in the neighbourhoods, the project, through the help of OMAU, can count on the assistance of a key tool, the GIS. This will provide us with an initial analysis of the zones where the activity will occur, thereby giveing us an understanding the layout of the district, types of trading, situation of recycling containers, demographics etc. This tool, which information is shown through a file such as the one shown in Figure 3, allows us to optimise the organisation of the action, maximising impacts.

Once the zone has been studied and the action plan designed, the ALAs will go into the street (Figures 4 and 5) on foot to start the awareness campaign. This campaign
3. Análisis de la zona de actuación y área de influencia / Analysis of the action zone and area of influence.

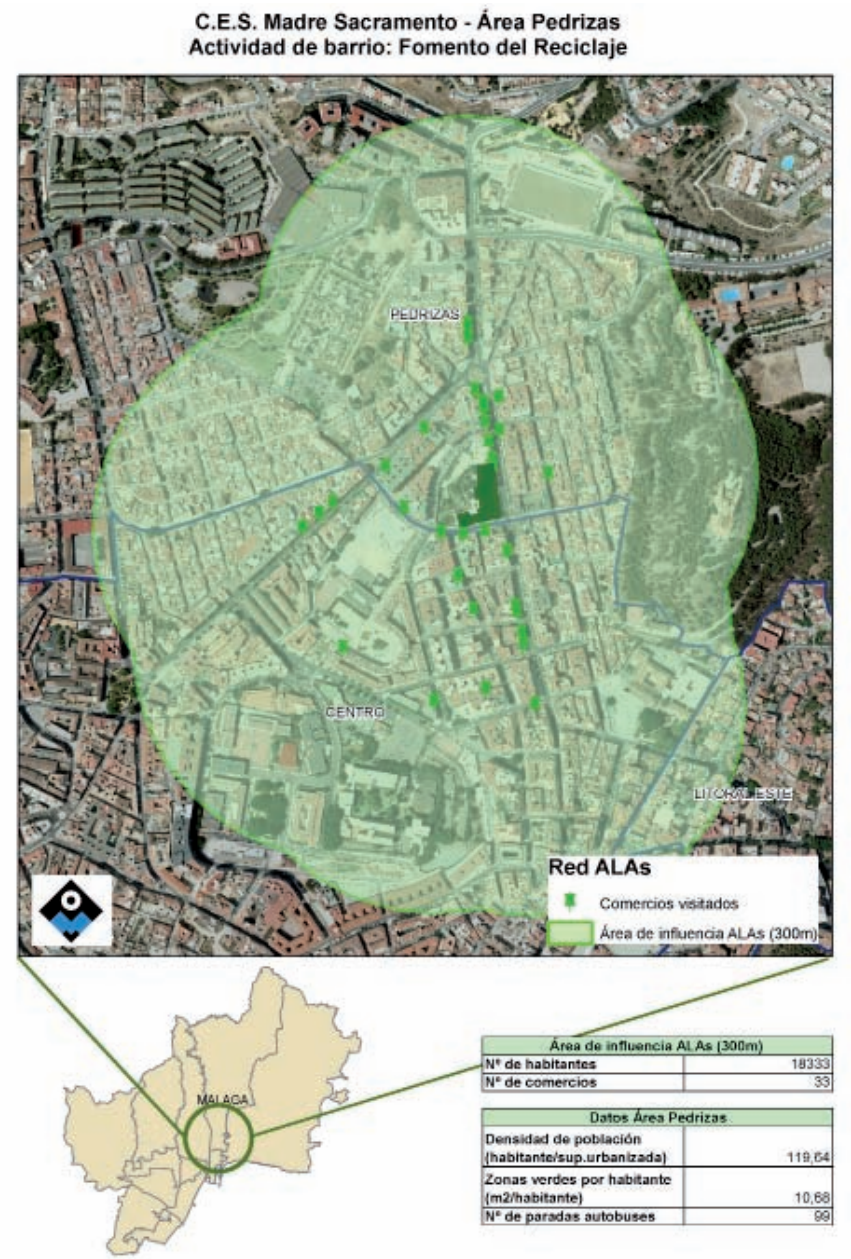


4 y 5 . Acción directa en los Barrios - Direct action in the neighborhoods.

6. Ficha de seguimiento de la acción / Monitoring Chart showing action in the neighborhood.

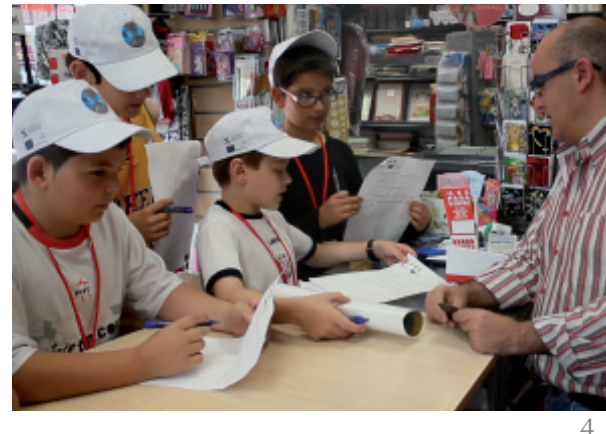

Una vez estudiada la zona y diseñado el plan de acción, los ALAs salen a la calle (Figuras 4 y 5) para hacer la campaña de concienciación a los ciudadanos de a pié, sus vecinos del barrio, informando, haciendo encuestas y entregando material divulgativo con los aspectos básicos de las campañas. Igualmente visitan los comercios informando y colocando carteles, en definitiva, haciendo partícipes directos de la acción a sus barrios. Esta acción viene apoyada por voluntarios de la Universidad de Málaga que colaboran en el proyecto, apoyando a los niños para la captación de dos elementos clave:

- Comercios asociados. Identificados a través de pegatinas, como comercio colaborador de los Agentes Locales Ambientales de Málaga.

- Hogares interesados en participar como Hogares Verdes ALA que nos permitirán medir el impacto de las actuaciones y los resultados, además de en los colegios, en los barrios.

De esta forma se consigue una acción directa a través de las personas encuestadas, los comercios visitados y los hogares verdes asociados y una acción indirecta a través del área de influencia ALAs que se estima en unos 300 metros alrededor de cada comercio visitado.

Cada actividad de barrio se concreta en una fi cha de seguimiento, como la mostrada en la Figura 6, que incluye
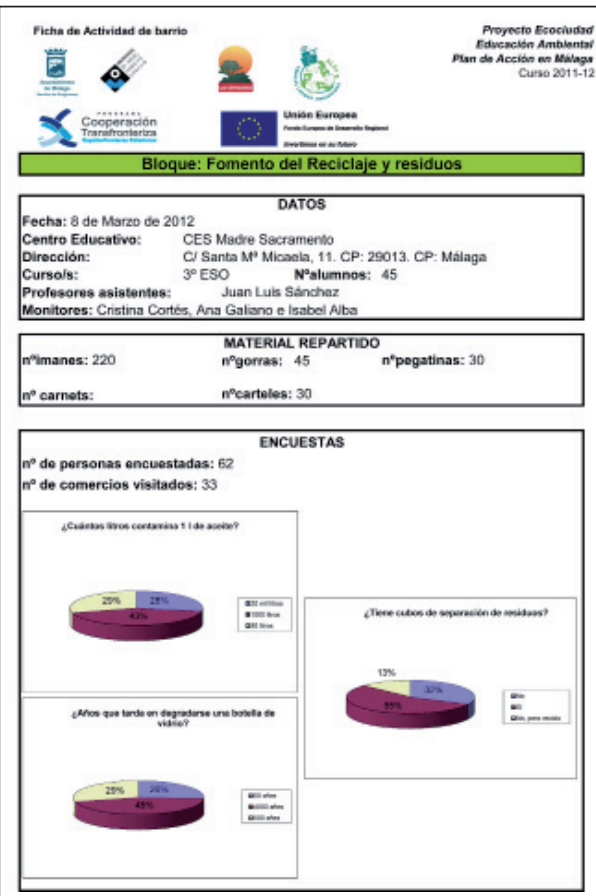

los resultados obtenidos en la actuación así como indicadores que a través del GIS nos permiten medir el impacto directo e indirecto de la acción.

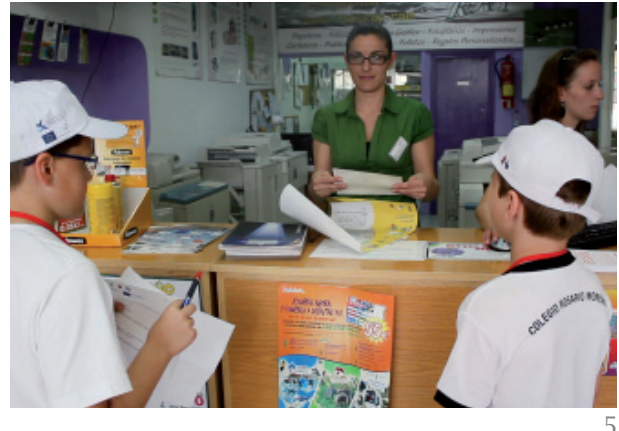

is directed to the citizens and their neighbours, who will be informed about the basic aspects of the campaign through questionnaires and the distribution of informative material. At the same time they will visit shopkeepers, distributing information and putting up posters, in short, becoming direct contributors to the events happening in their neighbourhood. These actions will be supported by volunteers from the University of Málaga collaborating in the project, and supporting the children to identify two key players:

- Associated shopkeepers. They will get identified by stickers, as collaborating businesses with the Local Environment Agents of Málaga.

- Households interested in participating as 'Green Homes' which will allow us to measure the impact of the actions and the results not only in schools but in the neighbourhoods.

By carrying out these activities, we achieve both a direct and indirect impact. The direct impact will be achieved through people interviewed, shopkeepers visited and the 'green homes' associated with project. The indirect impact has been estimated at around a $300 \mathrm{~m}$ radius from each trader visited.

Each district's activity will be recorded on a 'monitoring chart', as the one shown in Figure 6 which will include the results of the events as indicators which, by means of the GIS, will permit us to measure the direct and indirect impact of the action. 
Además de las actuaciones en los barrios, los ALAs, desarrollan el mismo tipo de acción con motivo de efemérides como el Día Mundial de la Tierra (simultánea en todas las ciudades ALAs), en el corazón del Centro Histórico. Las imágenes incluidas en las Figuras 7 y 8 , muestran una actuación en la calle principal del centro.

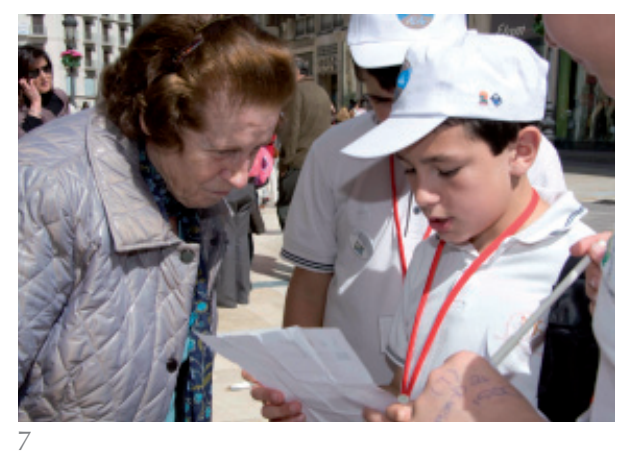

\subsubsection{Medición y ámbitos de actuación}

La medición de los resultados obtenidos por cada centro educativo se realiza mediante un baremo entre el indicador cuantitativo aplicado a cada bloque de actuación (indicador adaptado de la Agenda 21) y el indicador cualitativo (valoración por un jurado, de actividades paralelas realizadas y material promocional y audiovisual aportado por cada centro de forma voluntaria). Las Tablas 1 y 2 muestran el ejemplo de tablas de resultados para las campañas de energía y reciclaje. Esta combinación nos permite valorar tanto los resultados reales obtenidos en las actividades como el esfuerzo realizado por cada centro educativo. Tras varios años de trabajo con los centros educativos, se ha
Besides the activities in the neighborhoods, the ALAs will commemorate key annual events linked to urban environment such as the "Earth Day", simultaneously in all cities integrating the network, in the hart of the historic centre. Figures 7 and 8 show a direct action in the city's main street.

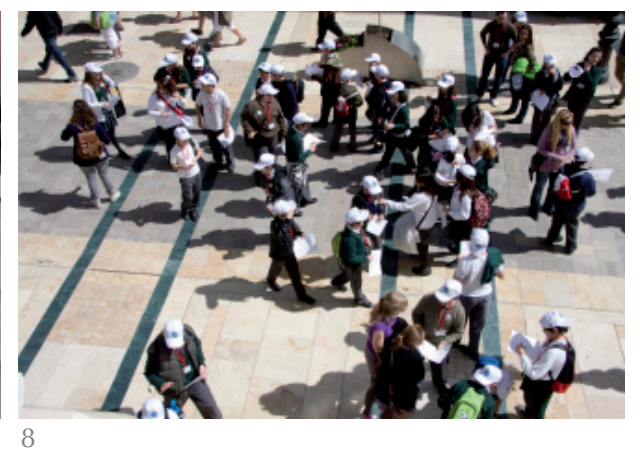

\subsubsection{Assessment and action zones}

The assessment of the results obtained for each school will be measured on a scale between the quantitative indicator applied to each initiative (an indicator adapted from Local Agenda 21) and the qualitative indicator (assessed by a body of parallel activities carried out, and promotional and audiovisual material provided voluntarily by each centre), Tables 1 and 2 show the example of result's chart for energy \& recycling. This combination allows us to value both the real results obtained as well as the effort made by each school. After several years of continuous work with the schools, it has been noticed that the best results are those of the
7 y 8 . Acción directa en el Centro Histórico / Direct action in the City Center.

Tabla 1. Resultados correspondientes a la campaña de Energía (2011-2012) / Table 1. Results' Chart for the Energy Initiative (2011-2012)

\begin{tabular}{|l|l|l|l|l|}
\hline \multicolumn{1}{|c|}{ CENTROS PARTICIPANTES EN EL BLOQUE AHORRO Y USO EFICIENTE DE LA ENERGÍA 2011/12 } \\
\hline & $\begin{array}{c}\text { Alumnos } \\
\text { totales }\end{array}$ & \multicolumn{1}{|c|}{ Ahorro $(\mathrm{Kw} / \mathrm{h})$} & $\begin{array}{c}\text { \% } \\
\text { ahorro }\end{array}$ & $\begin{array}{c}\text { Material aportado } \\
\text { por el centro }\end{array}$ \\
\hline CEIP La Cañada & 24 & $-1008,026$ & 8,3 & \\
\hline Colegio SAFA-ICET & 200 & -700 & 15,56 & \\
\hline Colegio Academia Santa Teresa & 705 & datos no presentados & & \\
\hline CEIP Jorge Guillén & 300 & 107,36 & 8,65 & \\
\hline Colegio St. George School & 800 & -2316 & 19,3 & \\
\hline IES Martin de Aldehuela & 450 & datos no presentados & & \\
\hline CEIP Angel Ganivet & 320 & 127,21 & 9,35 & \\
\hline CES Madre Sacramento & 420 & datos no presentados & & \\
\hline Colegio Cristo Rey & 215 & 802,55 & $-6,19$ & \\
\hline IES Sierra Bermeja & 640 & 575,89 & $-5,67$ & pegatinas y carteles \\
ahorro energía
\end{tabular}


Tabla 2. Resultados correspondientes a la campaña de Reciclaje (2011-2012).

Table 2. Results' Chart for the Recycling Initiative (2011-2012).

\begin{tabular}{|c|c|c|c|c|c|c|}
\hline \multicolumn{7}{|c|}{ CENTROS PARTICIPANTES EN EL BLOQUE RESIDUOS Y FOMENTO DEL RECICLAJE 2011/12 } \\
\hline Centro & $\begin{array}{l}\mathrm{n}^{\mathrm{o}} \\
\text { ALAs }\end{array}$ & $\begin{array}{l}\text { Alumnos } \\
\text { totales }\end{array}$ & $\begin{array}{l}\text { Indicador (kilos } \\
\text { pilas } / \mathrm{n}^{\circ} \text { alumnos) }\end{array}$ & $\begin{array}{c}\text { Indicador (I aceite/ } \\
\mathbf{n}^{\circ} \text { alumnos) }\end{array}$ & $\begin{array}{c}\text { Media de Ambos } \\
\text { Indicadores }\end{array}$ & Otros \\
\hline CEIP Miguel Hernández & 146 & 146 & 0,06 & & 0,03 & Separación residuos \\
\hline CEIP La Cañada & 24 & 24 & 2,21 & 0,63 & 1,42 & $\begin{array}{l}\text { Fotos múltiples talleres, } \\
\text { jabón, esculturas, etc. }\end{array}$ \\
\hline Escuelas SAFA-ICET & 64 & 200 & 0,06 & & 0,03 & \\
\hline CEIP Jorge Guillén & 50 & 300 & 0,03 & 0,015 & & $\begin{array}{l}\text { Ropa(75 kilos) y } \\
\text { toners (2 kilos) }\end{array}$ \\
\hline Colegio St. Georges School & 50 & 800 & 0,01 & 0,06 & 0,03 & Ropa(200 kilos) \\
\hline Colegio Cerrado de Calderón & 50 & 448 & 0,02 & & 0,01 & \\
\hline Colegio La Asunción & 12 & 1064 & 0,41 & 0,3 & 0,35 & RAEES(95 kilos) \\
\hline CEIP Nuestra Señora de Gracia & 36 & 170 & 0,01 & & 0,005 & \\
\hline IES Martin de Aldehuela & 80 & 600 & 0,02 & & 0,01 & \\
\hline CEIP Angel Ganivet & 200 & 320 & 0,01 & & 0,005 & \\
\hline CES Madre Sacramento & 45 & 420 & 0,02 & & 0,01 & Talleres reciclaje \\
\hline Colegio Cristo Rey & 40 & 215 & 0,09 & & 0,045 & \\
\hline IES Sierra Bermeja & 80 & 640 & 0,02 & & 0,01 & \\
\hline IES Jardines de Puerta Oscura & 25 & 371 & 0,02 & & 0,01 & \\
\hline CEIP Manolo Garvayo & 30 & 425 & 0,09 & & 0,05 & \\
\hline CEIP Camino de San Rafael & 50 & 326 & & & & \\
\hline IES Christine Picasso & 30 & 293 & 0,01 & & 0,005 & \\
\hline CES San José & 45 & 360 & 0,93 & 1,36 & 1,15 & RAEES(655 kilos) \\
\hline CEIP Felix Revello de Toro & 53 & 450 & 0,08 & & 0,04 & RAEES(20 kilos) \\
\hline CEIP Pintor Denis Belgrano & 50 & 440 & 0,01 & & 0,005 & \\
\hline CEIP Victoria Kent & 50 & 250 & 0,01 & 0,84 & 0,42 & RAEES(30 kilos) \\
\hline IES Mare Nostrum & 40 & 472 & & 0,006 & 0,003 & RAEES(50 Kilos) \\
\hline IES Santa Bárbara & 63 & 1090 & 0,01 & & 0,005 & Toners(22 kilos) \\
\hline CEIP Virgen de Belén & 250 & 667 & 0,02 & & 0,01 & RAEES \\
\hline CEIP Los Guindos & 50 & 466 & 0,03 & & 0,015 & \\
\hline CEIP Paulo Freire & 60 & 725 & & 0,24 & 0,12 & \\
\hline Colegio Espíritu Santo & 50 & 669 & 0,08 & & 0,04 & \\
\hline Colegio Ave María & 110 & 1200 & 0,01 & 1,7 & 0,86 & RAEES(600 kilos) \\
\hline Colegio Santa Luisa de Marillac & 30 & 300 & 0,07 & & 0,035 & Reciclaje tapones \\
\hline IES Emilio Prados & 90 & 600 & 0,01 & 0,18 & 0,09 & \\
\hline CEIP Padre Jacobo & 53 & 310 & 0,09 & & 0,045 & \\
\hline Colegio Rosario Moreno & 26 & 600 & 0,16 & & 0,08 & \\
\hline IES M $M^{a}$ Victoria Atencia & 42 & 208 & 0,04 & & 0,02 & \\
\hline IES Campanillas & 110 & 670 & & & & \\
\hline CEIP Cupiana & 65 & 147 & 0,03 & & 0,015 & \\
\hline CEIP Cayetano Bolívar & 48 & 485 & 0,13 & & 0,065 & \\
\hline CEIP Manuel Fernández & 60 & 640 & 0,08 & & 0,04 & \\
\hline SEP Puerto de la Torre & 120 & 60 & 0,02 & & 0,01 & \\
\hline
\end{tabular}

comprobado como los colegios con mejores resultados son los que cuentan con mayor número de profesores implicados. Los profesores son clave en el desarrollo exitoso de las acciones, no solo por su capacidad de convocatoria y motivación con el alumnado sino por las aportaciones que realizan para la optimización de las acciones.

La efectividad de las acciones de barrio, está siempre ligada a compacidad y la complejidad del mismo. Los barrios con mayor compacidad edificatoria favorecen no solo densidades más altas sino mayor diversidad de usos y funciones en una misma zona gracias a los comercios de barrio.

Estas características que resultan en una proximidad de de servicios básicos a escala peatonal, favorece la interacción vecinal. El barrio conoce a los niños, son sus hijos, sus clientes, sus familiares y responden mejor ante su invitación a la participación. schools with a larger number of teachers involved. Teachers are key to the successful development of actions, not only for their capacity to motivate the kids but for what their contribution to the project actions improvement.

The effectiveness of the direct actions in the neighbourhoods, are always related to their compactness and complexity. Areas with a higher level of building compactness bring on not only higher densities but a higher diversity of uses and functions within a concrete area, thanks to the local shops \& business.

These features that result on a proximity to basic services at a pedestrian scale favour neighbourhood interaction. The neighbours knows the kids, their might be their children, their clients or part of their family and thanks to this fact, they answer better to the kids invitation to participate. 
La medición de los resultados obtenidos se realiza de la siguiente forma:

- Bloques por el Ahorro y uso racional del Agua y el Ahorro y uso eficiente de la Energía:

Los colegios facilitan los recibos de agua y luz desde el mes de inicio hasta el final de la Campaña y se estudia la tendencia. El indicador en este caso será la diferencia del consumo antes y después de la campaña dividida por el total de alumnos del centro.

\section{- Bloque de Fomento del Reciclaje:} Los Centros participantes en este bloque recibirán un contenedor (donado al OMAU por IKEA Málaga para su uso en los colegios participantes) en el cual se depositan las pilas recogidas por alumnos, familiares y vecinos así como contenedores para el reciclado de aceite. Posteriormente se procede a la recogida y peso de los contenedores. El indicador se calculará dividiendo los kilos de pilas recogidos durante el curso entre el número total de alumnos del centro.

\section{- Bloque de Movilidad Sostenible:}

Antes de la realización del taller se pasa un cuestionario a los alumnos del centro que nos permite conocer los hábitos de desplazamiento que emplean los alumnos de cada colegio y que se le volverá a repetir a fin de curso para medir la posible influencia del taller en sus desplazamientos habituales. Además se tendrá en cuenta la participación en actividades opcionales relacionadas con la bicicleta.

\section{- Bloque de Cohesión Social:}

Muy ligado a la cooperación, trabaja valores de sostenibilidad social como tolerancia y buena vecindad. Partiendo de la promoción de un barrio donde converjan viviendas libres con sociales, distintas generaciones y distintas culturas, se involucra al vecindario en campañas de recogida de artículos que puedan ser destinados a los más necesitados a través del concepto de "ciclo de vida" (9) de los productos. El indicador se obtiene dividiendo los kilos de material (según la campaña) recogidos durante el curso entre el número total de alumnos del centro.

\subsubsection{Incentivos}

Esta última fase pretende motivar a los protagonistas del proyecto, alumnos y profesores de los centros ganadores, a través del reconocimiento público de su participación en la mejora de la sostenibilidad de su ciudad (Figura 9). Cada ámbito de actuación tiene un centro ganador según la pondera-
The assessment of the results obtained will be carried out in the following way:

- Initiative for the conservation and reasonable use of water, and the conservation and efficient use of energy: Schools will provide water and electricity bills from the first month until the end of the campaign and the trends will be studied. The indicator in this case will be the difference in consumption from before and after the campaign, divided by the total number of students in the centre.

\section{- Initiative to encourage recycling:}

The centres participating in this initiative will receive a container (donated to the OMAU by IKEA Málaga for use in participating schools) where used batteries collected by pupils, relatives and neighbours can be deposited, in addition to containers for recycling cooking oil. Ultimately the containers will be collected and weighed. The result will be calculated by dividing the weight of the batteries collected during the school term by the total number of pupils at the school.

\section{- Initiative for Sustainable Mobility:} Before the development of the workshop, a questionnaire is filled out by the school student which allows us to find out how they get to school. This questionnaire is repeated at the end of the school year to measure the possible impact of the workshop in their daily trips. The extra participation in optional actions related to the use of the bicycle will be taken in account.

\section{- Initiative for Social Cohesion:}

Integrally linked to the project are the values of social sustainability, such as tolerance and good neighbourliness. Starting with the promotion of a district where both social and free market housing are found in addition to the coexistence of different generations and cultures, the community will be involved in campaigns to collect items which can be forwarded to the most needy through the concept of 'product life cycle'. The indicative result will be obtained by dividing the weight of the items collected during the term (depending on the campaign) by the total number of pupils in the school.

\subsubsection{Incentives}

This last phase attempts to motivate the key members of the project, the pupils and teachers of the selected centres, through the public recognition of their participation in the improvement of the sustainability of their city (Figure 9). Each initiative 
9. Entrega de premios a los COlegios participantes / Award ceremony for the winning schools. ción de los resultados de los indicadores y las actividades complementarias que hayan realizado de forma voluntaria. Además se contempla la posibilidad de Menciones de Honor a centros que, a pesar de no tener el mejor resultado, hayan realizado un esfuerzo meritorio. Los centros educativos ganadores recibirán un premio, por lo general en forma de material de apoyo para las clases ligado a la temática del proyecto mientras los alumnos ganadores disfrutan de una visita al Aula de Naturaleza Las Contadoras de los Montes de Málaga. La entrega oficial de premios se realiza en el OMAU, de la mano de los responsables de los organismos participantes en cada edición, en un acto oficial con cobertura mediática. will have a winning centre according to the weighting of the indicative results and the complementary activities which may be undertaken voluntarily. There is the additional possibility of 'Special Mentions' for centres which, despite not having the best results, have shown a considerable effort. The winning schools will receive a prize, usually in the form of support materials for classes linked to the project's theme, while the winning pupils will enjoy a visit to the Nature Centre 'Las Contadoras' in the Malaga hills. The official presentation of prizes will take place at an official event at the OMAU and be given out by the organisations participating at each stage, and have media coverage.

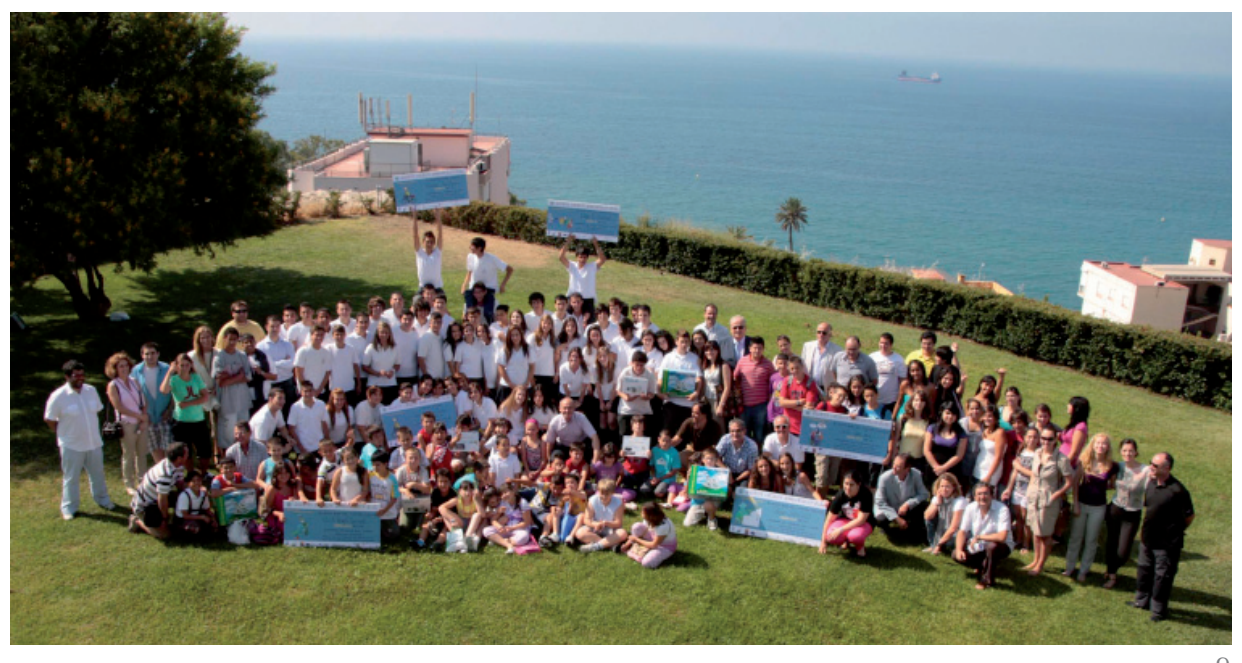

\section{CONCLUSIONES}

Con un presupuesto anual de $40.000 €$ el proyecto financia la participación de 40 colegios, lo que equivale a unos 3400 alumnos acreditados como Agentes Locales Ambientales. Algunas de las cifras manejadas (campaña ref. 2011-2012): son:

- 62 actividades de barrio,

- 700 comercios contactados

- 100 familias verdes ALAs

- 75 actividades en los centros educativos

- 23 colegios visitan el Observatorio de Medio Ambiente

- 3398 L de aceite usado recogido para su reciclaje.

- 58\% de los colegios participantes disminuyen el gasto energético

- $60 \%$ de los colegios participantes disminuyen el consumo de agua

- $1400 \mathrm{Kg}$ de pilas usadas recogidas.

Trabajamos por un modelo urbano que mezcla niveles suficientes de compacidad urbana y una elevada complejidad en la mezcla de usos y funciones. Un modelo de ciudad más eficiente que favorezca por su configuración, la comunicación y

\section{CONCLUSIONS}

With an annual budget of 40,000€, the project will finance the participation of 40 schools, which is equivalent to 3400 pupils accredited with the title 'Local Environment Agent'. Some of the numbers (based on 2012-2013 campaign) are:

- 62 activities in the neighborhoods

- 700 shopkeepers involved

- 100 green ALAs homes

- 75 activities in schools

- 23 schools to visit the Urban Environment Observatory (OMAU)

- 3398 litres of used oil to be collected for recycling

- $58 \%$ of the schools participating will reduce their energy costs

- $60 \%$ of the schools participating will reduce their water consumption

- $1400 \mathrm{~kg}$ of used batteries collected.

We work to promote a sustainable urban model which combines sufficient levels of urban density and compactness with a variety of uses and functions. A model of a more efficient city which favors, through its planning, the communication and exchange 
el intercambio de bienes y servicios entre los ciudadanos a una escala peatonal. Este modelo no es posible sin la participación ciudadana, sin la conexión entre los ámbitos técnico, político y ciudadano para modificar conductas urbanas hasta ahora consumidoras de recursos. El Sistema Educativo, como un subsistema dentro de la ciudad, posee un enorme potencial para influir y abanderar mejoras profundas en las sociedades en general y en el ámbito local en particular. Los niños y jóvenes tienen un papel fundamental como líderes naturales. Su auto-organización respaldada por actores clave de la ciudad que representen el conocimiento, la toma de decisiones y la ciudadanía, les apoya en su necesaria autonomía para participar activamente en la mejora de sus barrios y por el efecto multiplicador de sus acciones, en la calidad de vida de sus ciudades. La medición del impacto de las acciones en los barrios y su repercusión sobre la variación de los indicadores de sostenibilidad de la ciudad, es aún reto sobre el que trabajar.

\section{AGRADECIMIENTOS}

Nuestro agradecimiento a todos los que hacen posible el avance y crecimiento de este proyecto: desde su diseño y coordinación por parte del Aula de la Naturaleza Las Contadoras de Málaga y el equipo del Observatorio de Medio Ambiente Urbano de Málaga, hasta su ejecución: Asociaciones Madre Coraje y Ruedas Redondas, Empresa Malagueña de Transportes (EMT), Agencia Municipal de Energía, Plan de Movilidad Sostenible, IKEA y principalmente a los profesores y alumnos de los colegios que lo hacen posible. of goods and services between citizens on a pedestrian level. This model is not possible without the citizen's participation and the interaction between technical and political representatives and the general public to modify urban conduct, which up until now has been based on the consumption of resources. The Education System, as a subsystem within the city, has the enormous potential to influence and fly the flag for profound improvements to society in general and the local environment on a smaller scale. Children and young people have a fundamental role as natural leaders. Their self-organisational skills, supported by key actors of the city who represent knowledge, decision making and the city's inhabitants, provide the necessary autonomy for them to participate actively in improving their own neighborhoods, and as a consequence of the multiplying effect, to improve the quality of life in the city as a whole. The measure of the impact of these actions in the neighborhoods and their repercussion on the variation of the city's sustainability indicators is a goal still to be worked on.

\section{ACKNOWLEDGEMENTS}

Our thanks go to all who are making this project possible: from it's design and coordination by the Malaga's Aula de la Naturaleza 'Las Contadoras' and the team at Malaga's Urban Environment Observatory (OMAU), to it's implementation by the associations 'Madre Coraje' and 'Ruedas Redondas', Malaga Transport Company (EMT), the Municipal Energy Agency and the Municipal Plan for Sustainable Mobility, IKEA, and most importantly to the teachers and pupils, without them it would be impossible.

\section{FUENTES GENERALES DE INFORMACIÓN / GENERAL INFORMATION SOURCES}

- Guevara-Senciales, J.M., Nadales-Zayas, E. y Serrano-Alcantarilla, P. (2001). La atmósfera en la ciudad. Programa de educación y concienciación ambiental urbana. Málaga: Área de Medio Ambiente del Ayuntamiento de Málaga.

- Guevara-Senciales, J.M., Nadales-Zayas E. y Serrano-Alcantarilla, P. (2004). La naturaleza en la ciudad. Programa de educación y concienciación ambiental urbana. Málaga: Área de Medio Ambiente del Ayuntamiento de Málaga.

- $\quad$ Observatorio de Medio Ambiente Urbano (2010). Indicadores de sostenibilidad 2010. Agenda 21 Málaga. Servicio de Programas del Ayuntamiento de Málaga.

- Observatorio de Medio Ambiente Urbano (2010). Agentes Locales Ambientales hacia la ciudad sostenible. Agenda 21 Málaga. Servicio de Programas del Ayuntamiento de Málaga.

- Doval-Cotrino, A., Moreno-Atencia, P. y Sostema Sociedad Civil. (2010). Málaga sostenibilidad 2009. Málaga: Área de sostenibilidad, delegación de Medio Ambiente y Articulación territorial de la Diputación Provincial de Málaga.

- Observatorio de la sostenibilidad en España (2008). Sostenibilidad Local. Una aproximación urbana y rural. Madrid: Mundi prensa.

- Observatorio de la sostenibilidad en España. (2010). Sostenibilidad en España 2010. Madrid: Mundi prensa.

- $\quad$ Abbás-Montoya, S. y Narváez-Ledesma, L. (2009). El cambio climático, una realidad que nos afecta a todos. Málaga: Área de Medio Ambiente del Ayuntamiento de Málaga. 
- EnerAgen. (2010). La revista sobre energía para escolares. Málaga: Agencia Municipal de la Energía, Ayuntamiento de Málaga.

- Fundación BBVA (2007). Actitudes sociales de los españoles hacia la energía y el agua. Fundación BBVA. Recuperado Agosto 8, 2011 desde <http://www.aop.es/informes/presentacion_energia_agua.pdf>

- Fundación BBVA (2008). Percepciones y actitudes de los españoles hacia el calentamiento global. Fundación BBVA. Recuperado Agosto 8, 2011 desde www.mma.es/ ceneam <http://www.mma.es/ceneam>

- Tilbury, D. (1995). Environmental Education for sustainability: defining the new focus of Environmental Education in the 1990s. Environmental Education Research, 1(2): 195-211.

- Geoffrey, A. (2011). Las redes sociales, ¿ Las nuevas tecnologías de comunicación para la educación y sensibilización ambiental del mañana?. Segovia: CENEAM

- Consejería de Medio Ambiente. (2006). Estrategia Andaluza de Educación Ambiental. Sevilla: Consejería de Medio Ambiente, Junta de Andalucía.

- Dirección general de Desarrollo Sostenible e Información Ambiental. (2010). Ecobarómetro andaluz. Sevilla: Consejería de Medio Ambiente, Junta de Andalucía.

- Ministerio de Medio Ambiente. (1999). Libro blanco de la educación ambiental. Madrid: Ministerio de Medio Ambiente.

- Área de Medio Ambiente del Cabildo de Tenerife. (2009). El manual del hogar verde, pequeños gestos para un mundo más sostenible. Tenerife: Unidad de educación ambiental.

- CENEAM (Director).(2011). Hogares verdes, cómo dinamizar un programa para mejorar el comportamiento ecológico en el hogar [DVD]. Segovia: CENEAM.

\section{REFERENCIAS / REFERENCES}

(1) Observatorio de Medio Ambiente Urbano. (2006). Hacia la ciudad sostenible. Agenda 21 Málaga 05. Servicio de Programas del Ayuntamiento de Málaga

(2) (2007a) Carta de Leipzig sobre ciudades europeas sostenibles. Leipzig. Cita: Ciudades y cambio global en España. Fernando Prats Palazuelo

(3) Gro Harlem Brundtland et al. 1987. Report of the World Commission on Environment and Development: Our Common Future (Brundtland-Report).

(4) Comisión de las Comunidades Europeas. (1990). El Libro Verde sobre el Medio Ambiente Urbano. Dirección General de Medio Ambiente, Seguridad Nuclear y Protección Civil. EUR 12902 ES. Ref.: CD-NA12902-ES-C. Bruselas (Bélgica).

(5) Carta Verde de Málaga, Agenda Local 21. Fundación Ciedes de Málaga.

(6) Ministerio de Medio Ambiente. (1999). Libro blanco de la educación ambiental. Madrid.

Consejería de Medio Ambiente (2006). Estrategia Andaluza de Educación Ambiental. Sevilla: Consejería de Medio Ambiente, Junta de Andalucía.

Dirección general de Desarrollo Sostenible e Información Ambiental (2010). Ecobarómetro andaluz. Consejería de Medio Ambiente, Junta de Andalucía. Sevilla.

(7) Observatorio de Medio Ambiente Urbano. (2010). Agentes Locales Ambientales hacia la ciudad sostenible. Agenda 21 Málaga. Servicio de Programas del Ayuntamiento de Málaga.

(8) Perea, A. (2009). Hogares Verdes, participa desde tu casa en un reto colectivo. Opcions, 29.

(9) De Smet, B., White, P.R., Owens, J.W. (1996). Integración de la evaluación del ciclo de vida dentro de un marco global para la gestión medioambiental. (Integrating life cycle assessment within an overall framework for environmental management.) En Curran M A, ed. Environmental Life Cycle Assessment, McGraw-Hill Companies, New-York.

(10) Guevara-Senciales, J.M., Nadales-Zayas, E. y Serrano-Alcantarilla, P. (1998). El ciclo del agua en la ciudad. Programa de educación y concienciación ambiental. Área de Medio Ambiente del Ayuntamiento de Málaga. 